\title{
Taxonomic and Serological Researches on the Phymaturus patagonicus Complex
}

\author{
J. M. Cei and L. P. Castro \\ Instituto Biologia Animal, Universidad Nacional de Cuyo, \\ Mendoza, Argentina
}

\begin{abstract}
Five subspecies of Phymaturus from Argentine Patagonia are identified: $P$. patagonicus patagonicus Koslowsky, $P$. patagonicus indistinctus subsp. nov., both from Chubut, $P$. patagonicus somuncurensis, subsp. nov. from Rio Negro, $P$. patagonicus zapalensis subsp. nov. from Neuquén, and $P$. patagonicus payuniae subsp. nov. from Southern Mendoza. Their morphological and ecological features are described according to their widespread but isolated distribution. Quantitative immunological analyses emphasize the close affinities of the 5 proposed subspecies and their more distant relationships to $P$. palluma which is sympatric with $P$. patagonicus in Mendoza and Neuquén.
\end{abstract}

\section{INTRODUCTION}

The history of Phymaturus patagonicus is interlaced with the history of the ancient Lacerta palluma Molina reported since 1782, from Chile, later quoted as Cordylus palluma Meyer (1795) or Stellio palluma Latreille (1801). The genus Phymaturus was proposed by Gravenhorst (1838) and a new species, Phymaturus patagonicus, was correctly identified by Koslowsky (1898) during the very important geographical expedition to the unexplored Patagonian lands, carried out in $\mathbf{1 8 9 6}$ by Francisco P. Moreno and the geological staff of the La Plata Museum (1897).

Since Koslowsky's discovery, this lizard has remained poorly known and rarely discussed. Phymaturus spurcus Barbour (1921) from Huanuluan, Rio Negro, Argentina, is synonymous with patagonicus. Burt and Burt (1931) and a number of later herpetologists (Donoso B., 1966, and Peters and Donoso B., 1970) considered patagonicus a subspecies of Phymaturus palluma (Molina), even though Koslowsky found the two forms sympatric in many areas of Patagonia. Others (Cei, 1969a; Gallardo, 1970; Liebermann, 1939) maintained the specific status for patagonicus.

The present paper is a general revision of all the known populations of Phymaturus patagonicus Koslowsky. These represent a complex of widespread but well defined geographical units extending between $36^{\circ}$ and $46^{\circ}$ South latitude (Fig. 1). Five subspecific taxa are proposed, based on our diagnosis and descriptions. The nominal form patagonicus patagonicus Koslowsky (Fig. 2) is easily referred, by means of its terra typica ("ravines alongside Chubut River") to the only possible localities of collection, in February 1896, such as indicated by the itinerary map of Fig. 3. Clefts near to Chubut River, between Dolavon and Las Plumas, are the probable true terra typica of Koslowsky. Specimens from this area, now in the Herpetological Collection of the Institute of Animal Biology, Mendoza, agree with the Koslowsky types. This form is distributed alongside the Chubut River to Paso de Indios; southwards it reaches the basaltic Meseta of Canquel $(900-1000 \mathrm{~m})$ and some populational variation is stressed. A new form (P. patagonicus indistinctus subsp. nov.), superficially studied, is proposed for the Southern Chubut population, near Musters lake.

North of Chubut River two subspecies are described, one from the volcanic plateau of Somuncura (Rio Negro), a very peculiar Patagonian center of endemism (Cei, 1969b,c; Donoso 


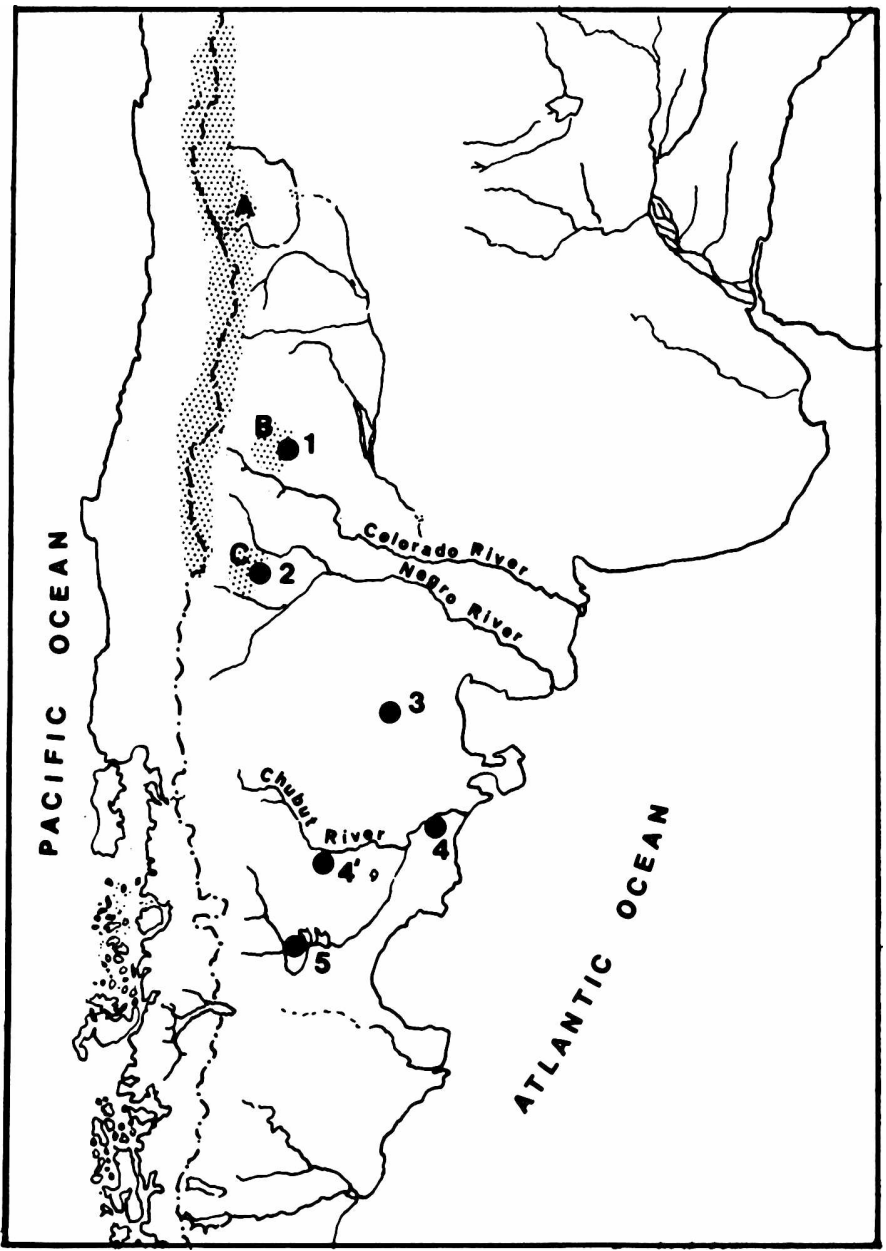

FIGURE 1. Geographical distribution of the subspecies of the Phymaturus patagonicus complex, 1.Phymaturus p. payuniae: 2-Phymaturus p. zapalensis: 3-Phymaturus p. somuncurensis; 4-Phymaturus $p$. patagonicus (Dolavon populations) and 4'-Phymaturus p. patagonicus (Paso de Indios populations); 5-Phymaturus p. indistinctus. Stippled areas: distribution of Phymaturus palluma populations: A-Cordilleran range; B-(Payún plateau) and C-(Zapala plateau), sympatric areas with Phymaturus patagonicus.

B. and Cei, 1971), the other from the volcanic tablelands, scattered by shallow lagoons, extending west of Zapala, Neuquén. They have been named $P$. patagonicus somuncurensis subsp. nov. and $P$. patagonicus zapalensis subsp. nov. A fifth form, $P$. patagonicus payuniae subsp. nov., is proposed for the population on the volcanic plateau surrounding the big peak of Payún Volcan $(3300 \mathrm{~m})$ in Mendoza Province.

The Phymaturus patagonicus complex is a significant herpetological element of the Patagonian biota, and it seems to be related constantly to late Tertiary volcanic landscape and basaltic environments. Each locality of its wide range is in the Patagonian phytogeographic realm. Stipa, Mulinum, Ephedra, Lycium, Berberis, Adesmia, Verbena, Grindellia, etc. are the predominant plants in the bush. These lizards are viviparous and phytophagous forms, feed on flowers of compositae, and shelter in the rock crevices and under stones. The climate of their habitat is dry and very continental, with cold winters and sunny summers, and with very wide range of daily thermal variation. Only the payuniae and zapalensis forms are sympatric with Phymaturus palluma in their own area of distribution.

Besides of the diagnosis and descriptions of the subspecies of patagonicus, extensive serological comparisons were made of the nominal form and zapalensis and payuniae, to add 


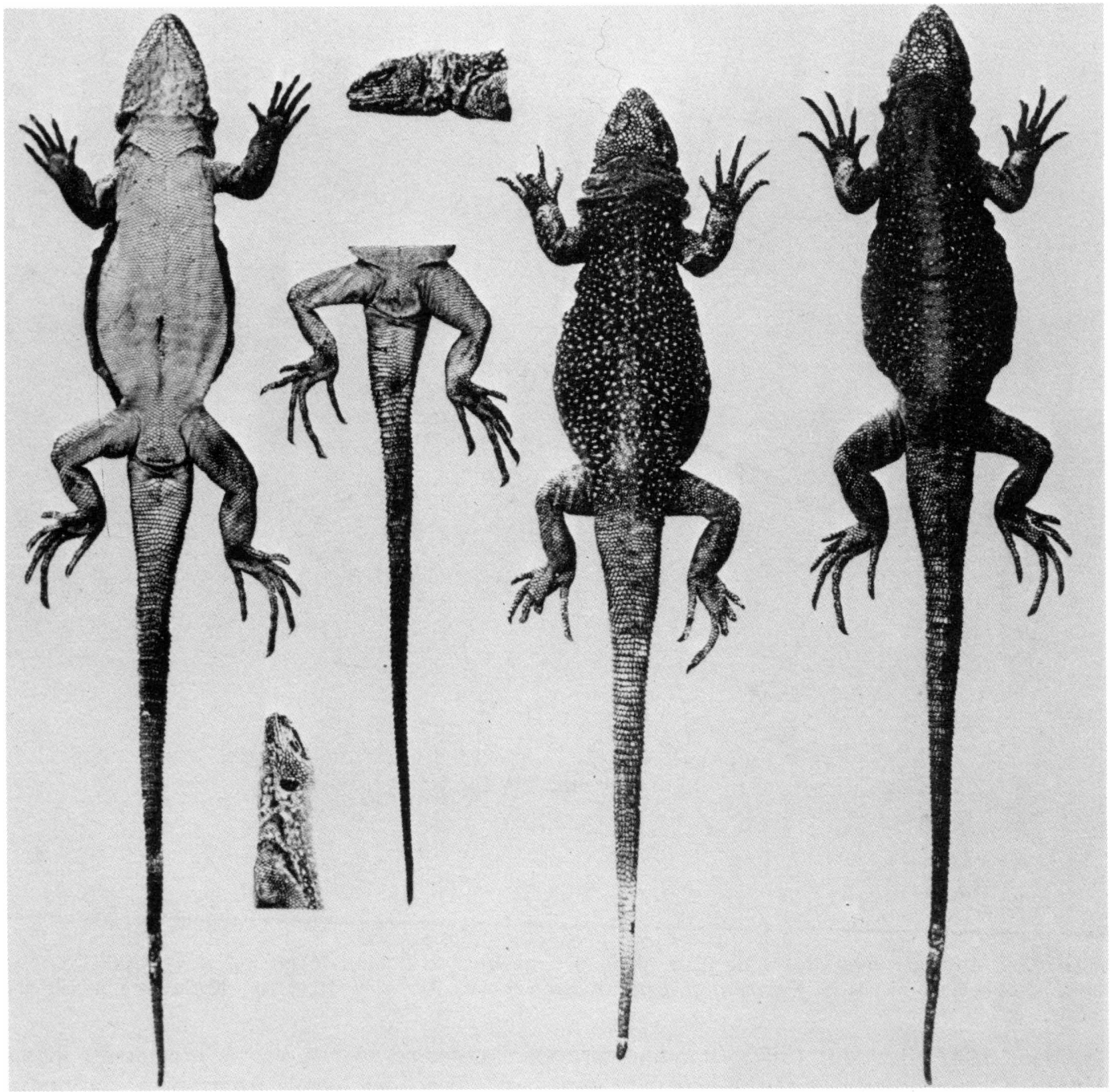

FIGURE 2. Phymaturus patagonicus Koslowsky (original plate; 1898).

another kind of information on the status of the geographic forms of patagonicus and their affinities with Phymaturus palluma.

\section{MATERIALS AND METHODS}

The samples used in immunological tests were collected between December 1971 and February 1972 in the areas of distribution of $P$. payuniae, zapalensis and patagonicus. The localities were: $5 \mathrm{~km}$ from Payún Volcan, Mendoza $(2000 \mathrm{~m})$, for Phymaturus patagonicus payuniae; Laguna Blanca and neighbouring lagoons, $35 \mathrm{~km}$ from Zapala, Neuquén (1200 m), for Phymaturus patagonicus zapalensis; Dolavon $(250 \mathrm{~m})$ and $50 \mathrm{~km}$ SE of Paso de Indios, Chubut $(600 \mathrm{~m})$ for Phymaturus patagonicus patagonicus. The localities for several earlier samples not used in immunological tests, are listed in the descriptions (paratypes). Blood samples, obtained by cardiac puncture, were allowed to clot and the resulting sera were stored at $-20 \mathrm{C}$, until needed. Precipitin titrations were carried out using the photronreflectometric technique described in papers of Boyden and colleagues (Boyden and De Falco, 1943; Bolton, Leone and 


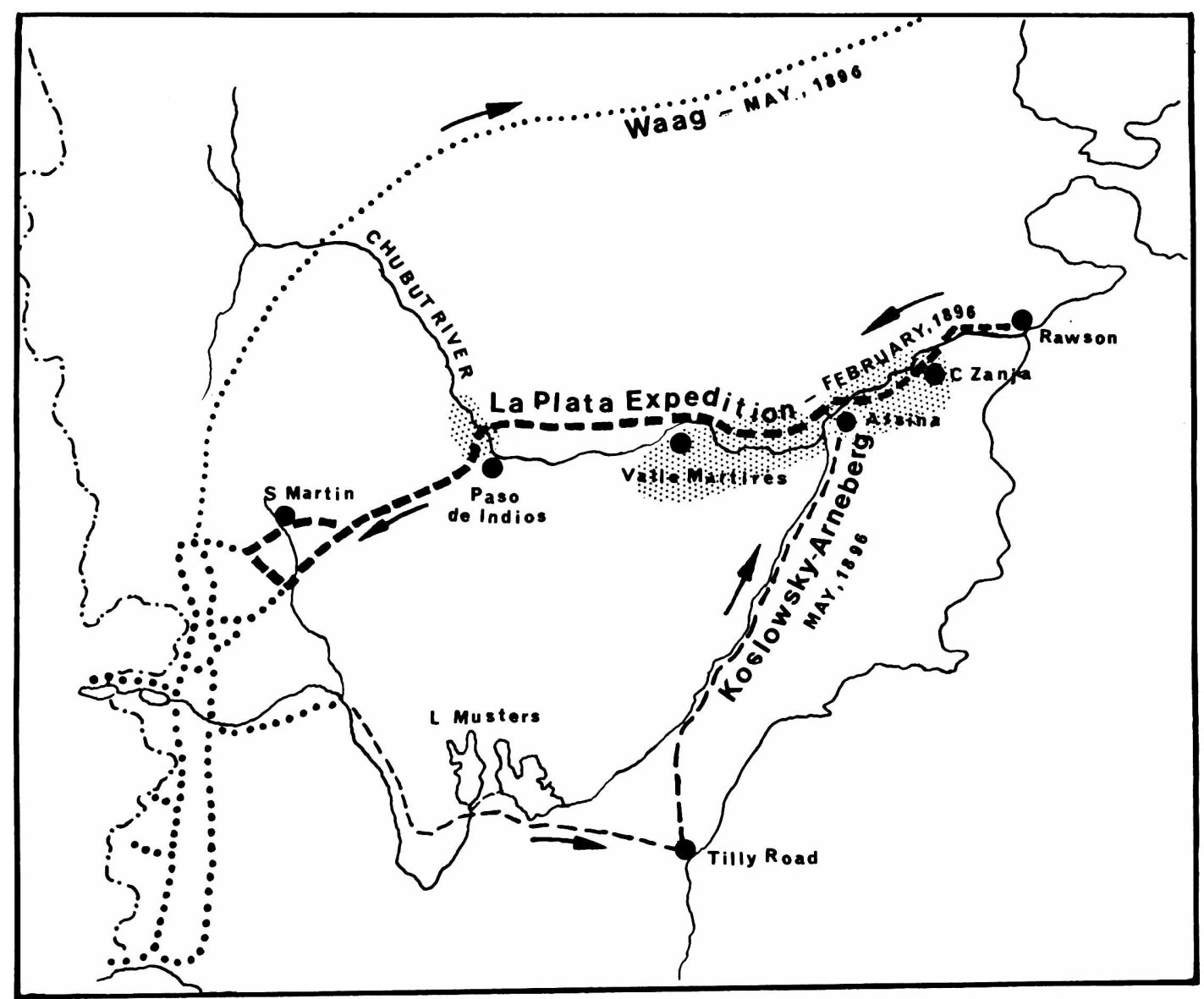

FIGURE 3. Itinerary map of the La Plata Museum Expedition to Chubut (February, May, 1896). Stippled area: probable localities of Phymaturus patagonicus samples, February 1896, by Koslowsky, Waag and Arneberg.

Boyden, 1947; Boyden, 1967). Immune sera were prepared in rabbits by progressive inoculations of strengthened antigens (Freund's Adjuvant). The homologous titrations of antibodies were made against a progressive series of dilutions of their own antigens. The results of these standard tests are considered as 100 per cent reaction. Heterologous titrations of the antibodies against a series of dilutions of a different antigen are reported relative to the homologous reaction. The metric measurements were made either with calibers of $0.5 \mathrm{~mm}$ precision, or with a stereomicroscope of $0.1 \mathrm{~mm}$ precision.

\section{DESCRIPTIONS \\ Phymaturus patagonicus patagonicus Koslowsky}

Holotype.-Herp. Coll. La Plata Museum. 1-an adult male. Terra typica: "ravines alongside Chubut River". Argentina. Taken February 1896 by Koslowsky, Waag and Arneberg. (Fig. 2; Fig. 4, A, A', B, B').

Paratype.-Herp. Coll. La Plata Museum. 2-same data as holotype.

Definition. -A Phymaturus lizard characterized by dorsal gray color scattered by plentiful whitish irregular flecks, without sex-dimorphic pattern; gular folds moderate; median dorsal granules slightly larger than lateral granules; caudal scales gently mucronate.

Distribution.-On ravines and rocks alongside the Chubut River, from Dolavon to Paso de Indios and Northern borders of Meseta Canquel, Chubut (above 250 to $1000 \mathrm{~m}$ ). 
Redescription.-To unify our taxonomic criterion a redescription of Koslowsky's form is given. A male specimen, snout-vent length $90 \mathrm{~mm}$, tail $124 \mathrm{~mm}$; head length $20 \mathrm{~mm}$, head width $17 \mathrm{~mm}$; hind leg $52 \mathrm{~mm}$. General aspect tall, the adpressed limb reaches the shoulder. Upper head scales somewhat rounded, small; small interparietal, 2 frontal scale rows; one scale row between the nasals and nostril; 8 temporal scale rows; 8 small supraorbitals, expanded; subocular expanded with a single series of small scales between labials and subocular; 8 supralabials and 7 infralabials. Ear opening vertically extended. Gular and antihumeral folds moderate. Dorsal scales small, rounded or granular. Ventral scales quadrangular, smooth, in transversal series: larger than dorsals. Caudal scales quadrangular, medially keeled, disposed in alternate slightly mucronate rows. Limb scales as in the body. Eight anal pores. 24 subdigital lamellae, with 4-5 keels. The live animal has a dark gray brown ground color, with many whitish spots given by 5-10 assembled white scales. Ventral surface gray or whitish with some black points on the throat. Tail with alternate paler or darker bands.

Variation. - In addition to the types of Koslowsky the following series have been studied: IBA.UNC. 789(1-7), Dolavon, Chubut, January 1972; IBA.UNC. 786(1-6), Paso de Indios, near
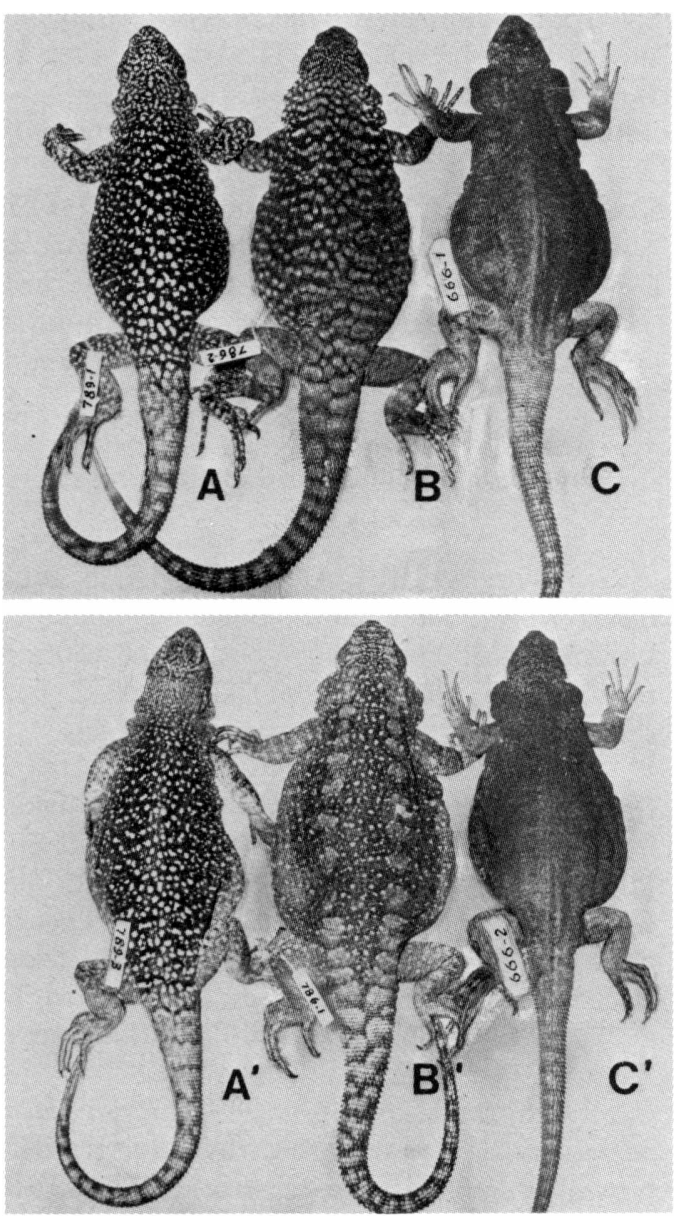

FIGURE 4. Male and female specimens of Phymaturus patagonicus patagonicus: $A$ and $A^{\prime}$ from Dolavon; $B$ and B' $^{\prime}$ from Paso de Indios; $C$ and $C^{\prime}$ male and female specimens of Phymaturus patagonicus indistinctus from Musters Lake. (The homeomorphism of $A$ and $A^{\prime}, C$ and $C^{\prime}$ must be emphasized).
Chubut River, Chubut, January 1972; IBA. UNC. 783(1-4), Sombrero, Chubut, January 1972; at all 9 males and 8 females, taken by J. M. Cei, L. M. Cei and T. Ferreyra. The following measurement of the males from Dolavon agree with the holotype: head length/head width; head length/body length; body length/ hind leg. However some populational trends of variation seem to exist between Dolavon and Paso de Indios-Sombrero samples (head length/body length: $0.27-0.32,4$ males Dolavon; 0.25-0.27, 4 males Paso de IndiosSombrero. Body length/hind leg: 1.30-1.34, 4 males Dolavon; 1.37-1.46, 4 males Paso de Indios-Sombrerol. Body measurement also point out some dimorphic sex characters. Head length/body length are 0.27-0.32 for 4 males and $0.25-0.26$ for 3 females, from Dolavon, 0.25-0.27 for 4 males and 0.23-0.25 for 4 females, from Paso de Indios-Sombrero; body length/hind leg are 1.30-1.34 for 4 males and 1.48-1.60 for 5 females, from Paso de Indios-Sombrero. Color patterns do not show sex differences in Dolavon samples, such as in the Koslowsky's type (Fig. 4 A, $A^{\prime}$ ). But in the western Paso de Indios-Sombrero populations a sex dichromatism is enough evident (Fig. 4 $\left.B, B^{\prime}\right)$. Dichromatism is there associated with a larger number (25-30) of white or reddish dorsal scales, assembled in the rounded lateral spots of the females.

\section{Phymaturus patagonicus indistinctus subsp. nov.}

Holotype. -IBA. UNC. 666-1-An adult male from Las Pulgas, $800 \mathrm{~m}, 50 \mathrm{~km}$ from Musters Lake, Chubut, Argentina, taken January 1970 by J. M. Cei, L. M. Cei and P. Mathioli. (Fig. 4 C, C'). 
Paratypes.-IBA. UNC. 666-2-3 (a male-a female). Same data as holotype.

Definition.-A subspecies of Phymaturus patagonicus characterized by dorsal gray brownish color, scattered by very scarce, small transversal dark spots; without any sex dimorphic pattern; gular fold very prominent; body stout with short hind legs.

Distribution. -Northern slopes of the Sierra San Bernardo, West of Musters Lake, Chubut.

Description-A male specimen, snout-vent $85 \mathrm{~mm}$, tail $100 \mathrm{~mm}$; head length $18 \mathrm{~mm}$, head width $15 \mathrm{~mm}$; hind leg $50 \mathrm{~mm}$. General aspect stout, the adpressed limb does not reach the shoulder. Upper head scales, supraorbitals, interparietal, frontals, temporals, as in the nominal form; suboculars, supralabials, infralabials as in the nominal form. Ear opening also vertically extended. Gular and antihumeral folds swelled, very evident. Dorsal scales small, granular, as in the nominal form. Ventral scales small $(1.2 \mathrm{~mm} ; 1.0 \mathrm{~mm}$ in patagonicus patagonicus $)$. Caudal scales mucronate, not disposed in alternate rows by their different size, as in the nominal form, but larger than in patagonicus patagonicus $(1.5 \mathrm{~mm} ; 1.2 \mathrm{~mm}$ in patagonicus patagonicus). 10 anal pores. 28 subdigital lamellae, with 5 keels. The live animals have a gray brownish uniform dorsal color, with scarce scattered transversal small spots. Ventral surface grayish unspotted, with evident pink-yellowish shades. Lack of any sex dichromatism. The males may be recognized only by the yellow anal pores. Tail profusely banded.

Variation. - The paratypes agree with the holotypes. Females have a very stout body, with shorter legs than the males.

Remarks. -The head length/body length of patagonicus indistinctus is lower $(0.20-0.22)$ than in the nominal form, and in the other subspecies. Also the hind legs are short in patagonicus indistinctus (body length/hind legs: 1.70-1.93 versus 1.30-1.60 of the other forms). The homeomorphism of this austral Phymaturus is really remarkable. They have been captured under stones, in the cooler hours of the early morning. Liolaemus bibroni and Homonota darwini were observed in the same place.
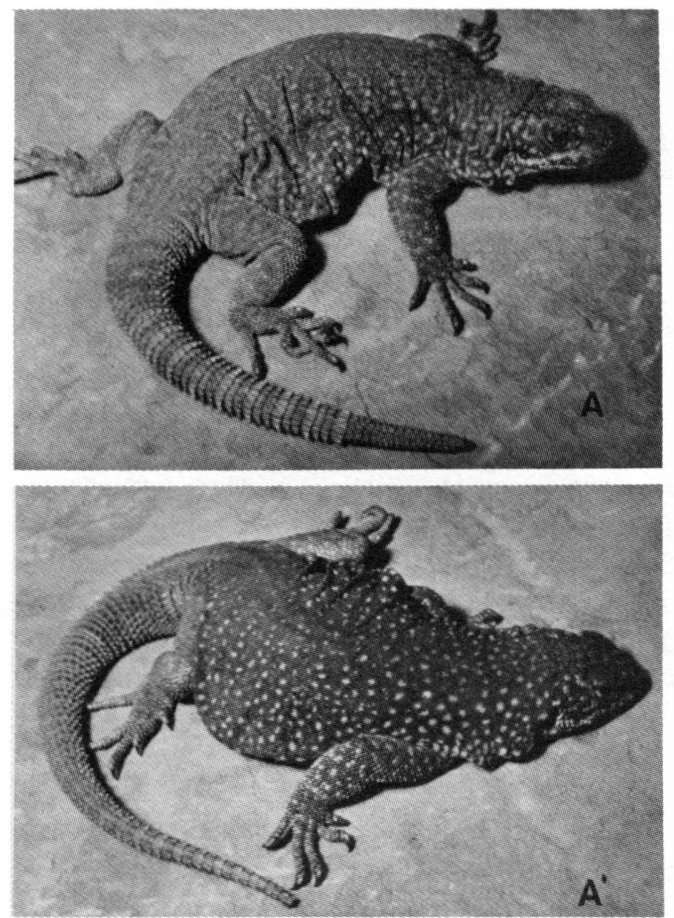

FIGURE 5. Phymaturus patagonicus somuncurensis subsp. nov; A-male, $A^{\prime}$-fermale.

\section{Phymaturus patagonicus somuncurensis subsp. nov.}

Holotype.-IBA. UNC. 470-1-An adult male from Somuncura Plateau, Raimunda Lagoon $(1400 \mathrm{~m})$, Rio Negro, Argentina, taken March 1968 by J. M. Cei and N. P. Tuzi (Fig. 5, $A, A^{\prime}$ ).

Paratypes.-IBA. UNC. 433-1-3, taken December 1967 by J. M. Cei; 470-2, taken March 1968 by J. M. Cei; 495 (1-2) and 507 (1-5), taken November 1968 by J. M. Cei and L. P. Castro: all near Raimunda Lagoon $(1400 \mathrm{~m})$, Somuncura Plateau; 508 (1-5) taken December 1968 by J. M. Cei, L. P. Castro, N. P. Tuzi, Cerro Corona $(1500 \mathrm{~m})$, Somuncura Plateau, Río Negro.

Definition.-A subspecies of Phymaturus patagonicus characterized by dorsal dark brownish color, with scarce and irregular whitish small spots; sex dimorphic pattern indistinct; gular folds moderate; head enlarged; ventral surface whitish gray pigmented throat; caudal scales mucronate; dorsal and ventral scales small.

Distribution.-Somuncura plateau, above $800 \mathrm{~m}$, Río Negro. 
Description. -A male specimen, snout-vent $90 \mathrm{~mm}$, tail $100 \mathrm{~mm}$, head length $17 \mathrm{~mm}$, head width $15 \mathrm{~mm}$, hind leg $44 \mathrm{~mm}$. General aspect stout, the adpressed limb does not reach the shoulder. Upper head scales, supraorbitals, interparietal, frontals, temporals, supralabials and infralabials as in the nominal form. Subocular divided in 2 asymmetrical scales. Gular and antihumeral folds less prominent. Dorsal scales smaller than in the nominal form, all of equal size and regularly arranged (in patagonicus patagonicus the size may vary and the scales of the white spots are larger). Ventral scales as in patagonicus patagonicus. Caudal scales mucronate, strong $(2.0 \mathrm{~mm}$ width), disposed in alternate rows (a row of larger and 2 rows of smaller scales, but 2 regularly alternate rows of larger and smaller scales in patagonicus patagonicus). 8 yellow anal pores. 26 subdigital lamellae with 5 keels. Color in living animal: dark brownish, with some whitish confused spots. Flanks somewhat darker. Ventral surface grayish with a strong pink-orange pigmentation. Throat gray, speckled. Sex dichromatism absent. Tail profusely banded.

Variation. - The paratypes agree with the holotype.

Remarks. - Head small, wider than in the patagonicus patagonicus form (head length/head width 1.06-1.13 versus 1.13-1.31, in the males) but narrower than in the subspecies from Neuquen and Mendoza. Other somatic differences appear with the populations from Chubut (body length/hind leg 1.47-1.68 versus 1.30-1.46, in the males: no difference with the Neuquen and Mendoza populations). Dorsal scales smaller than in patagonicus patagonicus both in patagonicus somuncurensis and in the Neuqúen and Mendoza populations. Ventral scales reduced in patagonicus somuncurensis and in Mendoza populations, but not in the subspecies of Neuquén. No clinal tendency may be thus supported for such a character. Phymaturus patagonicus somuncurensis live in the basaltic ravines of the extended Somuncura plateau. Other lizards from this comunity are Liolaemus rothi, Liolaemus bibroni, Liolaemus
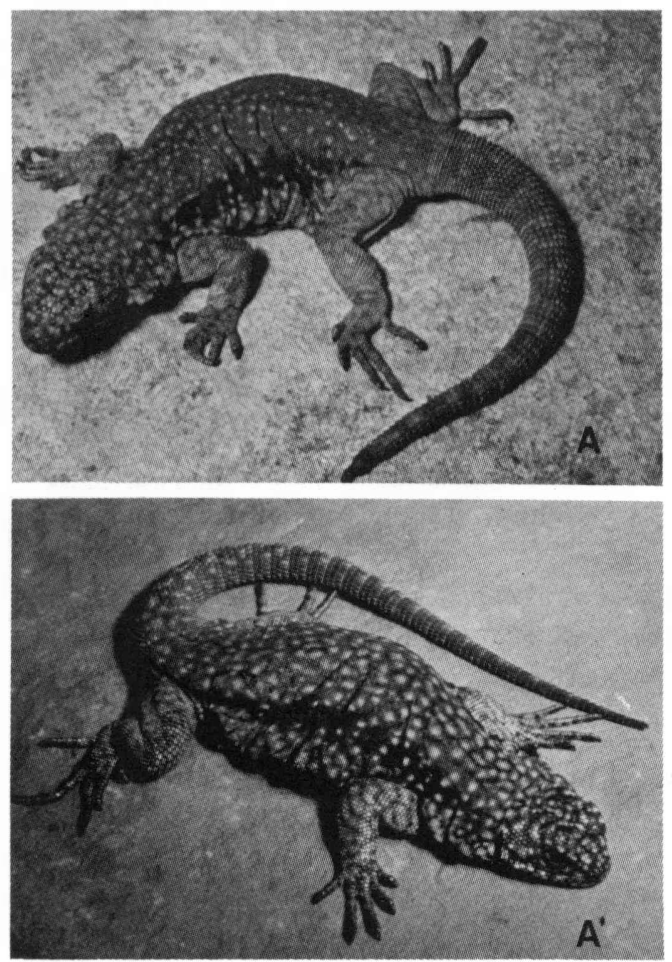

FIGURE 6. Phymaturus patagonicus zapalensis subsp. nov.; A-male, $A^{\prime}$-female. boulengeri and the endemic forms Liolaemus elongatus petrophilus and Liolaemus ruizleali. Also Diplolaemus darwini, D. bibroni and Homonota darwini are present.

Phymaturus patagonicus zapalensis subsp. nov.

Holotype.-IBA. UNC. 792-2-An adult male from Teru Lagoon, $1200 \mathrm{~m}, 40 \mathrm{~km} \mathrm{~W}$ Zapala, Neuquén, Argentina, taken January 1972 by J. M. Cei, L. M. Cei and T. Ferreyra (Fig. $6 \mathrm{~A}, \mathrm{~A}^{\prime}$ ).

Paratypes.-IBA. UNC. 349-1. Burro Lagoon, $1200 \mathrm{~m}, 48 \mathrm{~km} \mathrm{~W}$ Zapala, Neuquén, taken October 1966 by J. M. Cei and V. G. Roig; 436-1, Laguna Blanca, $1200 \mathrm{~m}, 30 \mathrm{~km}$ W Zapala, Neuquén, taken January 1968 by J. M. Cei; 590 (1-4), Casa de Piedra, 70 km SE Laguna Blanca, $1400 \mathrm{~m}$, Neuquén, taken January 1970 by J. M. Cei and L. M. Cei; 681 (1-7) Teru Lagoon, $1200 \mathrm{~m}, 40 \mathrm{~km}$ W Zapala, Neuquén, taken March 1970 by J. M. Cei and L. P. Castro; 792 (1-4) same data as holotype. Definition. -A subspecies of Phymaturus patagonicus characterized by dark brown dorsal color, with small and profuse whitish flecks and darker lateral bands, scattered by small rounded white spots; sex dimorphic 
pattern somewhat evident; gular folds moderate; head as long as wide; hind legs large and strong; caudal scales mucronate without alternate rows.

Distribution.-Rocky, volcanic highlands west Zapala, Neuquén, above $1000 \mathrm{~m}$.

Description.-A male specimen, snout-vent $86 \mathrm{~mm}$, tail $105 \mathrm{~mm}$, head length $17 \mathrm{~mm}$, head width $16.5 \mathrm{~mm}$ (head length $17 \mathrm{~mm}$ and head width $17 \mathrm{~mm}$ in some specimens), hind leg $50 \mathrm{~mm}$. General aspect tall, the adpressed limb reaches the shoulder. Head lepidosis and ear opening as in the nominal form. Gular and anti-humeral folds not too prominent. Dorsal scales as in patagonicus somuncurensis; ventral scales larger than in the nominal form $(1.2 \mathrm{~mm})$. Caudal scales mucronate, strong $(1.6-1.8 \mathrm{~mm})$, disposed without alternate rows. 12 orange anal pores. 30 subdigital lamellae, with 4-5 keels. Color in living animal dark brownish, scattered by small confused whitish flecks (5-12 scales). Lateral dark bands evident (darker in the females specimens), scattered by scarce white rounded spots. Ventral surface gray bluish with pink coloring and fine black spots on the throat. Tail also profusely banded.

Variation. - Paratypes similar to the holotype. The darker lateral bands may be more or less accentuate in the female specimens. Subdigital lamellae 30-33, the highest number in the species.

Remarks. - The wide head is a significant character of the subspecies (in the males, head length/head width 1.00-1.06 versus 1.12-1.31 for the nominal form); likewise the relative length of the hind leg (in the males, body length/hind leg 1.40-1.52 versus 1.30-1.40). Young specimens are very similar to the female specimens. These lizards are very nimble inhabitants of the rocky environments, near to the small basaltic lagoons. They are associated with Liolaemus elongatus elongatus, Liolaemus kriegi, Liolaemus bibroni, Diplolaemus darwini, Cupriguanus fasciatus, Homonota darwini, besides their related sympatric form Phymaturus palluma.
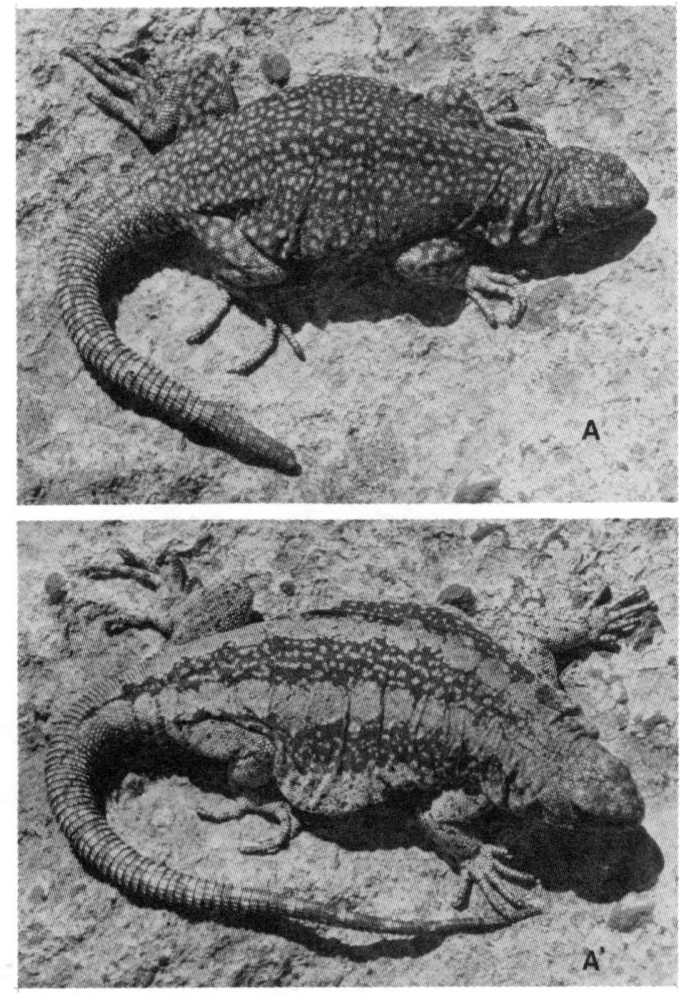

FIGURE 7. Phymaturus patagonicus payuniae subsp. nov.; A-male, A'female.
Phymaturus patagonicus payuniae subsp. nov.

Holotype.-IBA. UNC. 769-6-An adult male from Payún plateau, $5 \mathrm{~km}$ from the Payún Volcan, $2000 \mathrm{~m}$, South Mendoza Province, Argentina, taken December 1971 by J. M. Cei, L. P. Castro and T. Ferreyra (Fig. 7 $\left.A, A^{\prime}\right)$.

Paratypes.-IBA. UNC. $726(1-4), 734$ (1-2) taken January 1971 by L. P. Castro; 769 $(1-5,7,13,15,28), 787$ (1-5) taken January 1972 by J. M. Cei, L. P. Castro and T. Ferreyra: all same locality as holotype.

Definition.-A Phymaturus patagonicus subspecies characterized by a very strong sex dimorphism. Dorsal color of the males dark brown, scattered by evident but irregular white spots; dorsal color of the females black with lateral series of large, rounded whitish spots. Gular folds moderate. Head compressed, hind legs short. Caudal scales slightly mucronate, without alternate rows.

Distribution.-Isolated volcanic plateau of Payún (or Payunia), in the South of Mendoza Province, above $1600 \mathrm{~m}$.

Description.-A male specimen, snoutvent $85.5 \mathrm{~mm}$, tail $103 \mathrm{~mm}$, head length $17 \mathrm{~mm}$, head width $15 \mathrm{~mm}$, hind leg $47 \mathrm{~mm}$. 
General aspect tall, the adpressed limb scarcely reaches the shoulder. Head lepidosis and ear opening as in the nominal form. Gular and humeral folds moderate. Dorsal scales equally sized and regularly disposed, smaller than in patagonicus patagonicus. Ventral scales small. Caudal scales very slightly mucronate $(1.4 \mathrm{~mm}$, without alternate rows $\rangle .11$ yellow anal pores. 29 subdigital lamellae with 3-4 keels. Color in life: dorsally dark brown with plentiful scattered flecks of some 12-15 scales each; ventral surface whitish with scarce and very fine dark spots. Yellowish color on the posterior part of the belly and thighs. Tail with alternate spots and bands.

Variation. - Male paratypes as the holotypes. Female specimens characterized by a stouter body, shorter legs, and the lateral white larger spots of their symmetrical dorsal pattern (10-15 spots).

Remarks.-An apparently circumscribed geographical form. The juvenile specimens are very similar to the adult females, as it happens with the juvenile specimens of palluma, sympatric in the same area. We have found both species under the same stone or crevice, sometimes with Liolaemus elongatus and Homonota darwini. Lizards from the same habitat are Diplolaemus darwini, Cupriguanus fasciatus, Liolaemus boulengeri, Liolaemus bibroni and several others still undetermined species of Liolaemus.

\section{RESULTS OF SEROLOGICAL TESTS}

The results of the immunological reactions are given in the Table 1 . Besides their reciprocal tests, antigens of Phymaturus patagonicus patagonicus, $P$. patagonicus zapalensis and $P$. patagonicus payuniae, have been compared with those of sympatric Phymaturus palluma (from Payún, Mendoza and Laguna Blanca, near Zapala, Neuquén) and with an allopatric cordilleran population of the same species (from Paramillo, Mendoza, $3000 \mathrm{~m}$ ).

The data point up the close relationships of $P$. patagonicus from Mendoza, Neuquén and Chubut, with cross reactions falling invariably between 93 and 96 per cent. Subspecific status of these geographical forms is clearly suggested by these results, with the ranges falling within

TABLE 1. Immunological titrations" in the Phymaturus patagonicus complex.

\begin{tabular}{|c|c|c|c|c|c|c|c|}
\hline \multirow[b]{2}{*}{ antigens $^{3}$} & anti & $\begin{array}{l}\text { paturus } \\
\text { an }\end{array}$ & nicus & \multirow[b]{2}{*}{ pay } & \multicolumn{3}{|c|}{$\begin{array}{c}\text { Phymaturus palluma } \\
\text { antisera }\end{array}$} \\
\hline & pat $_{1}$ & pat $_{2}$ & zap & & $\mathrm{pal}_{1}$ & $\mathrm{pal}_{2}$ & $\mathrm{pal}_{3}$ \\
\hline $\begin{array}{l}\text { pat }_{1} \\
\text { pat }_{2} \\
\text { zap } \\
\text { pay }\end{array}$ & $\begin{array}{c}100^{4} \\
96 \\
95 \\
95\end{array}$ & $\begin{array}{r}94 \\
100 \\
93 \\
95\end{array}$ & $\begin{array}{r}93 \\
95 \\
100 \\
94\end{array}$ & $\begin{array}{r}96 \\
95 \\
96 \\
100\end{array}$ & $\begin{array}{l}74 \\
76 \\
77 \\
83\end{array}$ & $\begin{array}{l}78 \\
79 \\
77 \\
88\end{array}$ & $\begin{array}{l}74 \\
76 \\
79 \\
85\end{array}$ \\
\hline $\begin{array}{l}\mathrm{pal}_{1} \\
\mathrm{pal}_{2} \\
\mathrm{pal}_{3}\end{array}$ & $\begin{array}{l}75 \\
77 \\
75\end{array}$ & $\begin{array}{l}77 \\
78 \\
77\end{array}$ & $\begin{array}{l}76 \\
76 \\
77\end{array}$ & $\begin{array}{l}84 \\
85 \\
83\end{array}$ & $\begin{array}{r}100 \\
94 \\
92\end{array}$ & $\begin{array}{r}93 \\
100 \\
93\end{array}$ & $\begin{array}{r}90 \\
91 \\
100\end{array}$ \\
\hline Cup & 32 & 30 & & & & & 33 \\
\hline $\begin{array}{l}\text { Lio } \\
\text { Dip }\end{array}$ & & & & 35 & & 22 & \\
\hline
\end{tabular}

\footnotetext{
Abbreviations: pat $_{1}=P$. patagonicus patagonicus from Dolavon, Chubut. pat $2=P$. patagonicus patagonicus from Paso de Indios, Chubut. zap $=P$. patagonicus zapalensis from L. Blance, Neuquén. pay $=P$. patagonicus payuniae from Payún, Mendoza. $\mathrm{pal}_{1}=P$. palluma from Paramillo, Mendoza. pal $2=P$. palluma from Payún, Mendoza. $\mathrm{pal}_{3}=P$. palluma from Laguna Blanca, Neuquén. Cup $=$ Cupriguanus fasciatus from Payún, Mendoza. Lio $=$ Liolaemus sp. from Payún, Mendoza. Dip = Diplolaemus darwini from Payún, Mendoza. 2: sera of species indicated. 3: sera from rabbits immunized with sera of species indicated. 4: percent of cross reactivity using homologous reaction as $100 \%$ standard.
} 
extremes expected for natural genetic variation of the specific serum antigens. Similar results were obtained for the palluma complex (percentages ranging from 90 to 94 per cent). On the other hand the serological data clearly distinguished palluma and patagonicus with their cross-reactions falling between 74 and 79 per cent, except for reactions involving $P$. palluma and the payuniae sample of $P$. patagonicus. These titrations, involving the latter, were stronger, falling between 83 and 88 per cent indicating a closer serological relationship to palluma than the other patagonicus subspecies. This curious result cannot be easily referred to genetic interchange by interspecific hybridation in the Payún area of sympatry, because of the lack of similar findings in the case of the equally sympatric populations from Neuquén.

\section{DISCUSSION}

The Phymaturus genus includes 2 clear cut species: palluma and patagonicus. The $P$. palluma populations occur along both the eastern and western Andean slopes and in some extra-cordilleran basaltic plateau between $25^{\circ}$ and $40^{\circ}$ south latitude in Argentina. The patagonicus complex is a significant extra-cordilleran element of the Patagonian biota.

In spite of its geographical segregation and morphological differentiation, a whole specific status of $P$. patagonicus is supported by the immunological evidence. Such evidence also supports specific status for the subspecifically undifferentiated populations of $P$. palluma. Besides confirming Koslowsky's form, $P$. patagonicus patagonicus from Chubut River, our work indicates that the subspecies indistinctus, somuncurensis, zapalensis and payuniae are isolated by topography or other natural factor concerned with the specialized ecology of these lizards, which live in crevices of broken and rough basaltic rocks. The absence of clinal tendency in several of their somatic characters gives a first evidence of the independent selective regulation acting on genetic structures of the isolated populations of patagonicus.

A striking feature of the different patagonicus subspecies is the irregularity in the degree of sexual dimorphism. The strongly monomorphic form $P$. patagonicus indistinctus from southern Chubut is replaced along the Chubut River by the slightly dimorphic populations of $P$. patagonicus patagonicus. Northwards the slightly dimorphic subspecies zapalensis occurs but so does the monomorphic somuncurensis. North of the Colorado River the subspecies $P$. patagonicus payuniae exhibits the highest degree of sexual dimorphism of the species. We can advance no geographic or climatic reason for the present distribution of secondary sexcharacters in the patagonicus complex.

Sympatry in Mendoza and Neuquen territories, plus the morphological and serological evidences, eliminates any doubts concerning the conspecific status of Phymaturus palluma and $P$. patagonicus. The serological distance between members of the two species (74-79 per cent between palluma and patagonicus patagonicus or patagonicus zapalensis; $83-88$ per cent between palluma and patagonicus payuniae) is less than between Phymaturus and other Iguanid genera tested (cross reactions with Cupriguanus, Liolaemus, Diplolaemus lie between 22 and 35 per cent). No explanation of the closer serological relationships between $P$. patagonicus payuniae and $P$. palluma is forthcoming. Perhaps the payuniae form is genetically (or phylogenetically?) nearer to the ancestral palluma than the other forms. Antigenic structure of the sera could represent, in this case, remains of some past common genetic constitution. It is a suggestive observation that both young specimens of payuniae and palluma present similar pattern, quite indistinct at a first look.

\section{LITERATURE CITED}

Barbour, Th. 1921. On a small collection of reptiles from Argentina. Proc. Biol. Soc. Washington 34: $139-141$.

Bell, Th. 1843. Reptiles: in Zool. Voy. Beagle., 5, Londres; p. 1-51. 
Bolton, E. T., Ch. A. Leone, and A. A. Boyden. 1947. A critical analysis of the performance of the photronreflectometer in the measurement of serological and other turbid systems. J. Immun. 58(2): $169-181$.

Boyden, A. 1967. The place of precipitin testing among newer trends in taxonomy (Symposium on Newer Trends in taxonomy held at New Delhi on January 28-30, 1966). Bull. Nat. Inst. Sci. India 34:108-117.

and R. J. De Falco. 1943. Report on the use of the photronreflectometer in serological comparisons. Phys. Zoology 16(3):229-241.

Burt, C. E. and M. D. Burt. 1931. South American lizards in the collection of the American Museum of Natural History. Bull Amer. Mus. Nat. Hist. 61(7):227-395.

Cei, J. M. 1969a. Consideraciones sobre las relaciones taxonómicas de Phymaturus patagonicus y Phymaturus palluma. Com. II Jorn. Arg. Zool. Santa Fe, Paraná (Set. 1969). Acta Zool. Lilloana 28(2) $1971: 37-46$.

1969b. La meseta basáltica de Somuncurd, Río Negro, herpetofauna endémica y sus peculiares equilibrios biocenoticos. Physis 28,77:257-271. 1969c. The Patagonian Telmatobiid fauna of the Volcanic Somuncura Plateau. J. Herp. $3(1-2): 1-18$

Donoso Barros, R. 1966. Reptiles de Chile. Ed. Univ. Chile, Santiago.

and J. M. Cei. 1971. New lizards from the Volcanic Patagonian Plateau of Argentina. J. Herp. 5(3-4):89-95.

Gallardo, J. M. 1970. Saurios argentinos. II. Los lagartos patagónicos. Ciencia e Investigación 26(9):296-403.

Gravenhorst, J. L. C. 1838. Beiträge zur genauern Kenntnis einiger Eidechsengattungen. Nov. Act. Acad. Leop. Carol. 18(2):712-784.

Koslowsky, J. 1898. Enumeración sistemática $y$ distribución geograffica de los Reptiles argentinos. Rev. Mus. La Plata 8:161-200.

Latreille, P. A. 1801. (in Sonnini C. S. and Latreille P. A.) Hist. Nat. Rept. 2:38.

Liebermann, J. 1939. Catálogo sistemático y zoogeográfico de los Lacertilidos argentinos. Physis 16:61-82.

Meyer, C. 1795. Synop. Rept.:17.

Moreno, F. P. 1897. Notes préliminaires sur une excursion aux territoires du Neuquén, Río Negro, Chubut et Santa Cruz. Musée de La Plata, La Plata.

Peters, J. A. and Donoso Barros, R. 1970. Catalogue of the Neotropical Squamata: II-Lizards and Amphisbenians. United States Nat. Mus. Bull. 297. 